\title{
Antiviral activity of Ageratina havanensis and major chemical compounds from the most active fraction
}

Revista Brasileira de Farmacognosia Brazilian Journal of Pharmacognosy 21(5): 915-920, Sep./Oct. 2011

\author{
Gloria del Barrio,,"1 Iraida Spengler, ${ }^{2}$ Trina García, ${ }^{2}$ Annele \\ Roque, ${ }^{1}$ Ángel L. Álvarez, ${ }^{1,3}$ José S. Calderón, ${ }^{4}$ Francisco \\ Parra $^{3}$
}

${ }^{1}$ Departamento de Microbiología y Virología, Facultad de Biología, Universidad de la Habana, Cuba,

${ }^{2}$ Centro de Estudios de Productos Naturales, Facultad de Química, Universidad de La Habana, Cuba,

${ }^{3}$ Instituto Universitario de Biotecnología de Asturias, Departamento de Bioquímica y Biología Molecular, Universidad de Oviedo, España,

${ }^{4}$ Instituto de Química, Universidad Nacional Autónoma de México, México.

\begin{abstract}
The antiviral activity of extracts obtained from Ageratina havanensis (Kunth) R.M.King \& H.Rob., Asteraceae, against rabbit vesivirus (RaV) (Caliciviridae) and human herpes simplex viruses type 1 and 2 (HSV-1, HSV-2) (Herpesviridae) were analyzed, and the main metabolites from the most active extract were isolated and characterized. The antiviral properties were investigated by measuring the inhibition of viral-induced cytopathic effect in Vero cells. The strongest inhibitory effects were found for ethyl acetate extract from leaves ( $\mathrm{SI}=5$ for $\mathrm{RaV}$ and $\mathrm{SI}=5.4$ for $\mathrm{HSV}-1$ ). The crude ethyl acetate extract was further fractionated by chromatographic methods and the structures of isolated compounds were established through comprehensive spectroscopic analyses, including IR, 2D NMR and MS. Four flavonoids were identified: 5,4'-dihydroxy-7-methoxyflavanone (sakuranetin), 3,5,4'-trihydroxy-7-methoxyflavanone (7-methoxyaromadendrin), 4'-O$\beta$-D-glucosyl-5,3'-dihydroxy-7-methoxyflavanone (4'-O- $\beta$-D-glucosyl-7methoxy-eriodictyol) and 4'-O- $\beta$-D-glucosyl-5-hydroxy-7-methoxyflavanone (4'-O- $\beta$-D-glucosylsakuranetin). This is the first report on antiviral activity for Ageratina havanensis.
\end{abstract}

Article

Received 6 Jan 2011

Accepted 31 Jul 2011

Available online 2 Sep 2011

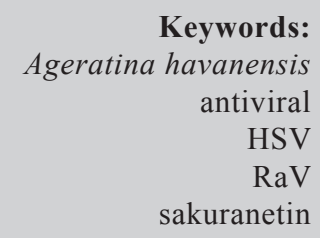

ISSN 0102-695X http://dx.doi.org/10.1590/S0102 $695 \times 2011005000159$

\section{Introduction}

The herpes simplex virus types 1 and 2 (HSV-1 and HSV-2) stand out because of the wide variety of clinical symptoms they cause, varying from mild self-limiting skin lesions to severe illnesses such as encephalitis and pneumonia, frequent among immune compromised patients. The relatively high toxicity of commercially-available synthetic anti herpes compounds, and the continuous spread of drug-resistant viral strains emphasize the need for new herpes inhibitors. Moreover, genital HSV lesions are associated to an increased risk of HIV acquisition (Freeman et al., 2006). On the other hand, the Caliciviridae includes many relevant human and animal pathogens, such as the human noroviruses which are the main causes of viral acute gastroenteritis outbreaks worldwide, and the rabbit hemorrhagic disease virus (RHDV), which is responsible for great economical losses due to devastation of entire domestic rabbit populations. Therefore, the search for novel anticaliciviral drugs also merits great attention. In addition, many caliciviruses do not replicate in cell cultures, thus making difficult their study. The rabbit vesivirus (RaV) is one of the few in vitro replicating caliciviruses and, for this reason, it is an excellent model to search for anticaliciviral agents (Martin-Alonso et al., 2005).

Ageratina (snakeroot) is a plant genus comprising about 250-290 perennials and rounded shrubs in the sunflower family, Asteraceae. Some species possess different biological properties, such as wound healing, cell proliferation stimulation and antimycotic action (Romero-Cerecero et al., 2008; Romero-Cerecero et al., 2011). Ageratina havanensis (Kunth) R. M. King \& H. Robinson (common name: Havana snakeroot) is a species of flowering shrub in this family, native of the Caribbean and Texas (Diggs et al., 1999). 
Since ancient times, plants have been widely used in traditional medicine by human populations. Chromones and flavonoids highlight among the most important naturally-occurring antiviral compounds (Torres et al., 2002). Flavones, flavonols and flavonoid glucosides were previously isolated from Ageratina havanensis (Yu et al., 1987). Although there is no evidence for antiviral use of this plant, other species in the Asteraceae have been used in folk medicine to treat gastrointestinal disorders, kidney affections and microbial infections (Romero-Cerecero et al., 2008). The present work reports for the first time the antiviral activity of $A$. havanensis against HSV-1, HSV-2 and $\mathrm{RaV}$, as well as the isolation and characterization of major compounds from the most active extract.

\section{Materials and Methods}

\section{Plant material}

Ageratina havanensis (Kunth) R.M.King \& H.Rob., Asteraceae (leaves and stems), was collected in Alamar (Havana) in November 2009 and identified by Prof. Iralys Ventosa from Instituto de Ecología y Sistemática (Havana, Cuba), where a voucher specimen was deposited (Ref. HAC-42498). The fresh leaves and stems were separated and oven-dried at $40{ }^{\circ} \mathrm{C}$, ground to fine powder (yielding $145 \mathrm{~g}$ and $284 \mathrm{~g}$, respectively) and stored in airtight bottles.

\section{Extraction and isolation}

The powdered oven-dried plant samples (from separate leaves and stems) were soaked in $n$-hexane and extracted with ethanol (EtOH). The EtOH extracts were concentrated by reduced pressure to yield syrup, further dissolved in water and extracted with ethyl acetate (EtOAc) and $n$-butanol $(n-\mathrm{BuOH})$ in a separating funnel. The resulting extracts were concentrated under reduced pressure in order to obtain the final EtOAc extracts (leaves yielded $11.12 \mathrm{~g}$ and stems yielded $1.55 \mathrm{~g})$ and $n-\mathrm{BuOH}$ extracts (leaves yielded $28.35 \mathrm{~g}$ and stems yielded 4.80 g).

The EtOAc extracts were further fractionated with an $n$-hexane/chloroform/methanol (2:1:1) mixture through Sephadex LH-20-packed column to give eleven fractions (A-K). Fractions I and J were purified by preparative thin-layer chromatography with a dichloromethane/methanol (9.7:0.3) mixture to give the compounds $\mathbf{1}$ and 2. Fraction E was chromatographed on silica gel using dichloromethane/methanol mixtures of increasing polarities. Compound 3 was obtained with $10 \%$ dichloromethane/methanol. The $\mathrm{G}$ fraction was further fractionated by column chromatography on silica gel with n-hexane/chloroform/methanol (2:3:0.5) to yield compound 4.
Compound 1: 5,4'-dihydroxy-7-methoxyflavanone (sakuranetin): white solid, m.p. $180-181{ }^{\circ} \mathrm{C}$, IR (KBr, $\left.\mathrm{cm}^{-1}\right)$ : 3450; 2990; 1640; 1605, 1450, 1370; 1280, 1260; 1090. MS 70eV $(\mathrm{m} / \mathrm{z}): 302\left(\mathrm{M}^{+}\right) ; 273\left(\mathrm{M}^{+}-29\right) ; 167\left(\mathrm{~A}_{1}+\right.$ $\mathrm{H})^{+} ; 136\left(\mathrm{~B}_{1}+\mathrm{H}_{2} \mathrm{O}\right)^{+}$.

Compound 2: 3,5,4'-trihydroxy-7-methoxyflavanone (7-methoxyaromadendrine): white solid, m.p. 154-156 ${ }^{\circ} \mathrm{C}$, IR $\left(\mathrm{KBr}, \mathrm{cm}^{-1}\right): 3530 ; 3452 ; 3356 ; 3144 ; 1622 ; 1512$; 1447; 1206; 1071. MS 70eV $(\mathrm{m} / \mathrm{z}): 286\left(\mathrm{M}^{+}\right) ; 285\left(\mathrm{M}^{+}-1\right)$; $167\left(\mathrm{~A}_{1}+\mathrm{H}\right)^{+} ; 120\left(\mathrm{~B}_{1}+2 \mathrm{H}\right)^{+}$.

Compound 3: 4'-O- $\beta$-D-glucosyl-5,3'-dihydroxy-7methoxyflavanone: white solid, m.p.206-207 ${ }^{\circ} \mathrm{C}$, IR $\left(\mathrm{cm}^{-1}\right)$ : 3200, 2840, 1668, 1580, 1370.

Compound 4: 4'-O- $\beta$-D-glucosyl-5-hydroxy-7methoxyflavanone: white solid, m.p. $201-204{ }^{\circ} \mathrm{C}$, IR $\left(\mathrm{cm}^{-1}\right)$ : 3420, 2940, 1625, 1490, 1380, 1260, 1200, 1140. HR-MS (FAB+) (m/z): $[\mathrm{M}+\mathrm{H}]^{+}: 449, \mathrm{C}_{22} \mathrm{H}_{24} \mathrm{O}_{10}$.

\section{Structure elucidation procedures}

The melting points (m.p.) were determined on a Reichert-Thermovar apparatus. The optical rotations were determined with a Perkin-Elmer 341 polarimeter. IR spectra were recorded on a Mattson Genesis spectrophotometer, series FT-IR. ${ }^{1} \mathrm{H}$ and ${ }^{13} \mathrm{C}$ NMR measurements were obtained on Varian Inova 400 and $600 \mathrm{MHz}$ NMR spectrometers with TMS as the internal reference. Mass spectra were recorded on Brucker Apex $70 \mathrm{eV}$. TLC was performed on $0.2 \mathrm{~mm}$-thick Kiesegel 60 F254 layers (Merck). Sephadex LH-20 and Silicagel (Merck) were used for column chromatography.

\section{Cytotoxic assays}

Vero cells (ATCC, CCL81) were seeded in 96well plates at a density of $2 \times 10^{4}$ cells/well, and incubated at $37{ }^{\circ} \mathrm{C}$ in a $5 \% \mathrm{CO}_{2}$ atmosphere for $48-72 \mathrm{~h}$, until $90 \%$ or greater confluence of the monolayers was reached. The cells were then incubated with increasing concentrations of the extracts at $37{ }^{\circ} \mathrm{C}$ in a $5 \% \mathrm{CO} 2$ atmosphere, for 72 h. Afterwards, a 3-(4,5-dimethylthiazol-2-yl)-2,5diphenyltetrazolium bromide (MTT) solution was added (final concentration $0.5 \mathrm{mg} / \mathrm{mL}$ ) and the plates were further incubated for $4 \mathrm{~h}$ to allow formazan production. The solid purple precipitate was dissolved with dimethylsulphoxide (Sigma) and the absorbance at 570 $\mathrm{nm}$ was measured using a $\mu$ QUANT Spectrophotometer (Bio-Tek Instruments) with a reference wavelength of $620 \mathrm{~nm}$. The concentration reducing cell viability by $50 \%$ (cytotoxic mean concentration, CC50) was calculated by regression analyses, as previously described (Mosmann, 1983). 


\section{Antiviral assays}

Ninety-six well plates containing confluent cell monolayers were pre-incubated for $1 \mathrm{~h}$ with increasing non-cytotoxic concentrations of the plant extracts, with a replicate number of six. Afterwards, the cells were infected with HSV-1, HSV-2 or RaV (10 $\left.\mathrm{TCID}_{50}\right)$. The plates were incubated at $37^{\circ} \mathrm{C}$ in a $5 \% \mathrm{CO}_{2}$ atmosphere and observed daily for viral-induced cytopathic effect (CPE) using a light microscope. The extract was present until the end of the experiment. When CPE was observed in all virus control wells, the percentage of wells with CPE was determined for each treatment concentration, as previously reported (Al Jabri et al., 1996). Acyclovir (ACV) at concentrations varying from $0.1-10 \mu \mathrm{g} / \mathrm{mL}$ served as positive control during HSV evaluations. A positive control for $\mathrm{RaV}$ is not yet available.

\section{Statistics}

Statistical analyses were performed using the Statistica 6.1 software. Differences among antiviral activity of extracts were determined using Student unpaired t-tests. Values of $p<0.05$ were considered indicative of statistical differences. The concentration reducing cell viability by $50 \%$ (mean cytotoxic concentration, CC50) and that reducing viral-induced CPE by $50 \%$ (antiviral effective mean concentration, EC50) were calculated by regression analyses using the dose-response curves (not shown) generated from the experimental data. A selectivity index (SI) was calculated for each test sample by dividing its CC50 by the corresponding EC50 value.

\section{Results and Discussion}

Cytotoxic effects and antiviral activity of Ageratina havanensis

The cytotoxic effects of samples on Vero cells were determined by the MTT colorimetric assay, as previously described (Mosmann, 1983). The influence of $A$. havanensis extracts on cell viability was indirectly measured as a function of the ability of mitochondrial enzymes (active in viable cells) to convert MTT in a purple solid formazan precipitate. All extracts exhibited concentration-dependent cytotoxic effects on Vero cells to different extents. Regarding the source of extracts, those obtained from leaves showed a higher toxicity when compared to their homologues from stems. On the other hand, when comparing extracts from the same plant organ, it should be mentioned that the $n-\mathrm{BuOH}$ extract was the most toxic, the EtOH the most innocuous, and the EtOAc exerted intermediate toxic effects (Table 1). The CC50 values found for $A$. havanensis extracts on Vero cells correlated well with the morphological changes recorded during microscopic examination of treated cultures. These alterations were gradual, concentration-dependent and comprised cell rounding, presence of cytoplasmic inclusions and loss of monolayer confluency.

The antiviral activity of extracts at noncytotoxic concentrations was assessed by measuring their protective effects on infected Vero cells (Al Jabri et al., 1996; Cann, 1999; del Barrio \& Parra 2000; Álvarez et al., 2011). SI values greater than 2 were considered indicative of specific antiviral activity (Tsuchiya et al., 1985; De Clercq, 1993). The first samples to be evaluated were the EtOH extracts from leaves and stems, since these were first generated during the extraction methodology. In view of the results obtained in this antiviral screening, we proceeded the fractionation by means of liquid-liquid partition chromatography with EtOAc and n-BuOH. The SI values increased with fractionation, as we should expect if the purification of antiviral compounds succeeded. The strongest antiviral activity was recorded for the EtOAc extract from leaves against $\mathrm{HSV}-1 \quad(\mathrm{SI}=5.4)$ and $\mathrm{RaV}$ $(\mathrm{SI}=5)$. The EtOAc extract from stems was also active against $\mathrm{RaV}(\mathrm{SI}=3.3)$. The anti-herpetic activity of this extract remains to be investigated since the maximum

Table 1. Cytotoxic effects and antiviral activity of extracts from Ageratina havanensis leaves and stems.

\begin{tabular}{|c|c|c|c|c|c|c|c|}
\hline \multirow{3}{*}{ Extract } & \multirow{3}{*}{$\begin{array}{c}\text { Cytotoxicity } \\
\text { CC50a }\end{array}$} & \multicolumn{6}{|c|}{ Antiviral activity } \\
\hline & & \multicolumn{2}{|c|}{ HSV-1 } & \multicolumn{2}{|c|}{ HSV-2 } & \multicolumn{2}{|c|}{$\mathrm{RaV}$} \\
\hline & & $\mathrm{EC} 50^{\mathrm{a}}$ & SI & EC50 & SI & EC50 & SI \\
\hline $\mathrm{EtOH}^{1}$ & $2834 \pm 448$ & $809.9 \pm 59.6$ & 3.5 & $1050 \pm 42.9$ & 2.7 & $1153 \pm 49.3$ & 2.5 \\
\hline EtOAc $^{1}$ & $1670 \pm 0.2$ & $311.6 \pm 10.1$ & 5.4 & $>450$ & $<4$ & $334.1^{\mathrm{b}}$ & 5.0 \\
\hline$n-\mathrm{BuOH}^{1}$ & $404.9 \pm 43.5$ & $>225$ & $<2$ & $128.1 \pm 22.8$ & 3.2 & $174.2 \pm 14.5$ & 2.3 \\
\hline $\mathrm{EtOH}^{\mathrm{s}}$ & $5685 \pm 117$ & $2628 \pm 103$ & 2.2 & $2614 \pm 158$ & 2.2 & $1307 \pm 206$ & 4.3 \\
\hline $\mathrm{EtOAc}^{\mathrm{s}}$ & $2270 \pm 99.9$ & $>450$ & $<5$ & $>450$ & $<5$ & $684.0^{\mathrm{b}}$ & 3.3 \\
\hline$n-\mathrm{BuOH}^{\mathrm{s}}$ & $457.4 \pm 28.1$ & $240.9 \pm 5.7$ & 1.9 & $145.4 \pm 22.1$ & 2.8 & $147.9 \pm 3.67$ & 3.1 \\
\hline $\mathrm{ACV}$ & $>1000$ & $0.9 \pm 0.2$ & $>1000$ & $0.7 \pm 0.1$ & $>1000$ & - & - \\
\hline
\end{tabular}

Data are presented as the mean value of two independent experiments and their standard deviations. ${ }^{\mathrm{a}} \mathrm{CC} 50$ and EC50 data are expressed as $\mu \mathrm{g} / \mathrm{mL}$

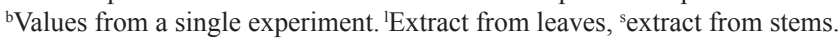


concentration tested against HSV-1 and HSV-2 did not reach the EC50 value $(\mathrm{SI}<5)$. On the other hand, no significant antiviral activity was observed for the $n$ - $\mathrm{BuOH}$ extracts against HSV-1 $(\mathrm{SI}<2)$. However these extracts were indeed active against the rest of viruses, with SI ranging from 2.3 to 3.2 (Table 1).

Several authors consider that the antiviral activity of compounds occurring in plants take place via a direct inactivating (virucidal) effect over the extracellular virus particle (Sydiskis et al., 1991). This may be especially true for enveloped viruses (e.g. HSV) which are more sensitive to physic and chemical disrupting agents. However, being $\mathrm{RaV}$ a non-enveloped and small virus, and consequently more resistant to external environmental agents, the antiviral activity found here is more attractive because A. havanensis compounds could hamper specific targets within the virus replication cycle, thus deserving further research. Based on its high SI values, the leaves EtOAc extract was selected for further purification of metabolites, as described below.

Structural data of compounds isolated from A. havanensis leaves ethyl acetate extracts

In order to isolate and characterize the major compounds in A. havanensis, a combination of column chromatographic techniques (Sephadex LH-20, silica gel and preparative thin-layer chromatography) was used. The structures of the isolated compounds were elucidated by physical and spectroscopic data measurements (m.p., IR, ${ }^{1} \mathrm{H}$ NMR, ${ }^{13} \mathrm{C}$ NMR, 2D NMR and MS) and by comparing the obtained data with previously published values.
The ${ }^{1} \mathrm{H}$ and ${ }^{13} \mathrm{C}-\mathrm{NMR}$ spectroscopic data obtained for these compounds (not shown) are consistent with previously reported values: Compound $\mathbf{1}$ was identified as 5,4'-dihydroxy-7-methoxyflavanone (sakuranetin) (Domínguez \& De la Fuente, 1973); compound 2 corresponded to 3,5,4'-trihydroxy-7-methoxyflavanone (7-methoxyaromadendrine) (Agrawal, 1989); compound 3 was identified as 4'- $O$ - $\beta$-D-glucosyl-5,3'-dihydroxy7-methoxyflavanone (4'-O- $\beta$-D-glucosyl-7-methoxyeriodictiol), previously isolated from the plant Aerva persica (Ahmed et al., 2006), but this is the first report for this glucoside in the Asteraceae; and compound 4 matched data for 4'- $O$ - $\beta$-D-glucosyl-5hydroxy-7-methoxyflavanone (4'-O- $\beta$-D-glucosyl-7methoxysakuranetin) (Zhang et al., 2006), which is a new flavonoid in the Ageratina genus.

Antiviral activities have been previously reported for several naturally-occurring flavonoids (Kaul et al., 1985; Kwon et al., 2010; He et al., 2011). It is known that some of them such as epigallocatechin gallate, epigallocatechin and quercetin, inhibited virusinduced cytopathic effects and reduced virus-plaque yields in Vero cells infected with HSV-1 and HSV-2 (Lyu et al., 2005). The antiherpetic activity of several flavonoid rich extracts from different plants has also been shown (Goncalves et al., 2001; Fernandez-Romero et al., 2003; Silva et al., 2010). Regarding their mechanism of action against herpes virus, it has been reported that flavonoids could have virucidal effects (Kaul et al., 1985; Hayashi et al., 1997; Goncalves et al., 2001) or act as inhibitors of the viral attachment and penetration (Isaacs et al., 2000; Silva et al., 2010).<smiles>COc1cc(O)c2c(c1)OC(c1ccc(O)cc1)CC2=O</smiles>

1<smiles>COc1cc(O)c2c(c1)O[C@H](c1ccc(O)cc1)[C@H](O)C2=O</smiles>

2<smiles>[R]c1cc(C2CC(=O)c3c(O)cc(OC)cc3O2)ccc1OC1OC(CO)C(O)[C@H](O)[C@H]1O</smiles>

$3 \mathrm{R}=\mathrm{OH}$

$4 \mathrm{R}=\mathrm{H}$ 
Further antiviral evaluations and mechanistic experiments are needed in order to elucidate the mechanism of action of metabolites isolated from $A$. havanensis.

\section{Concluding remarks}

The search for antiviral compounds among medicinal plants is actually a retrospective study aiming to establish the rationale for the use of products commonly employed by folk. The bioactivity-guided purification approach, partially followed in this work, has demonstrated to be an effective strategy to look for novel drugs. The outlined anti-HSV activities found for Ageratina havanensis suggest that EtOAc extract or derived compounds can be considered as phytopharmaceutical candidates for the treatment of herpetic infections. The results found using the in vitro anti-RaV model may also contribute to gain knowledge on calicivirus antiviral strategies. This is the first report on Ageratina havanensis antiviral activity. Further experiments are required to investigate the mechanism of action and the molecules responsible for the inhibition of specific viral targets.

\section{Acknowledgements}

This study was partially funded at F. Parra laboratory by AECID PCI grant D/030639/10. Financial support (grant: UNOV-10-BECDOC) given to Á. L. Álvarez by the University of Oviedo, is acknowledged.

\section{References}

Agrawal PK 1989. Carbon-13 NMR of flavonoids. Amsterdam: Elsevier.

Ahmed E, Imran M, Malik A, Ashraf M 2006. Antioxidant activity with flavonoidal constituents from Aerva persica. Arch Pharm Res 29: 343-347.

Al Jabri AA, Wigg MD, Oxford JS 1996. Initial in vitro screening of drug candidates for their potential antiviral activities. In: Mahy BWJ, Kangro HO (Eds.), Virology Methods Manual. Academic Press, p. 303-305.

Álvarez AL, Habtemariam S, Juan-Badaturuge M, Jackson C, Parra F 2011. In vitro anti HSV-1 and HSV-2 activity of Tanacetum vulgare extracts and isolated compounds: an approach to their mechanisms of action. Phytother Res 25: 296-301.

Cann A 1999. Antiviral testing. In Cann A (Ed.) Virus culture: a practical approach, New York: Oxford University Press, p. 201-219.

De Clercq E 1993. Antivirals for the treatment of herpesvirus infections. J Antimicrob Chemother 32 Suppl A: 121132.

del Barrio G, Parra F 2000. Evaluation of the antiviral activity of an aqueous extract from Phyllanthus orbicularis. $J$ Ethnopharmacol 72: 317-322.

Diggs GM, Lipscomb BL, O'Kennon RJ, Mahler WF, Shinners LH 1999. Shinners' and Mahler's illustrated flora of North Central Texas. Botanical Research Institute of Texas.

Domínguez XA, De la Fuente ER 1973. Sakuranetin and pulcherryl acetate from Eupatorium havanense. Phytochemistry 12: 2060.

Fernandez-Romero JA, del Barrio G, Romeu B, Gutierrez Y, Valdes S, Parra F 2003. In vitro antiviral activity of Phyllanthus orbicularis extracts against herpes simplex virus type 1. Phytother Res 17: 980-982.

Freeman EE, Weiss HA, Glynn JR, Cross PL, Whitworth JA, Hayes RJ 2006. Herpes simplex virus 2 infection increases HIV acquisition in men and women: systematic review and meta-analysis of longitudinal studies. AIDS 20: 73-83.

Goncalves JL, Leitao SG, Monache FD, Miranda MM, Santos MG, Romanos MT, Wigg MD 2001. In vitro antiviral effect of flavonoid-rich extracts of Vitex polygama (Verbenaceae) against acyclovir-resistant herpes simplex virus type 1. Phytomedicine 8: 477-480.

Hayashi K, Hayashi T, Otsuka H, Takeda Y 1997. Antiviral activity of 5,6,7-trimethoxyflavone and its potentiation of the antiherpes activity of acyclovir. J Antimicrob Chemother 39: 821-824.

He W, Li LX, Liao QJ, Liu CL, Chen XL 2011. Epigallocatechin gallate inhibits HBV DNA synthesis in a viral replication - inducible cell line. World J Gastroenterol 17: 15071514.

Isaacs CE, Xu W, Pullarkat RK, Kascsak R 2000. Retinoic acid reduces the yield of herpes simplex virus in Vero cells and alters the $N$-glycosylation of viral envelope proteins. Antiviral Res 47: 29-40.

Kaul TN, Middleton E Jr, Ogra PL 1985. Antiviral effect of flavonoids on human viruses. J Med Virol 15: 71-79.

Kwon HJ, Kim HH, Ryu YB, Kim JH, Jeong HJ, Lee SW, Chang JS, Cho KO, Rho MC, Park SJ, Lee WS 2010. In vitro anti-rotavirus activity of polyphenol compounds isolated from the roots of Glycyrrhiza uralensis. Bioorg Med.Chem., 18, 7668-7674.

Lyu SY, Rhim JY, Park WB 2005. Antiherpetic activities of flavonoids against herpes simplex virus type 1 (HSV-1) and type 2 (HSV-2) in vitro. Arch Pharm Res 28: 12931301.

Martin-Alonso JM, Skilling DE, Gonzalez-Molleda L, del BG, Machin A, Keefer NK, Matson DO, Iversen PL, Smith AW, Parra F 2005. Isolation and characterization of a new Vesivirus from rabbits. Virology 337: 373-383.

Mosmann T 1983. Rapid colorimetric assay for cellular growth and survival: application to proliferation and cytotoxicity assays. J Immunol Methods 65: 55-63.

Romero-Cerecero O, Zamilpa A, Jimenez-Ferrer JE, RojasBribiesca G, Roman-Ramos R, Tortoriello J 2008. 
Double-blind clinical trial for evaluating the effectiveness and tolerability of Ageratina pichinchensis extract on patients with mild to moderate onychomycosis. A comparative study with ciclopirox. Planta Med 74: 1430-1435.

Romero-Cerecero O, Zamilpa-Alvarez A, Ramos-Mora A, Alonso-Cortes D, Jimenez-Ferrer JE, Huerta-Reyes ME, Tortoriello J 2011. Effect on the wound healing process and in vitro cell proliferation by the medicinal mexican plant Ageratina pichinchensis. Planta Med 77: 979-983.

Silva IT, Costa GM, Stoco PH, Schenkel EP, Reginatto FH, Simoes CM 2010. In vitro antiherpes effects of a C-glycosylflavonoid-enriched fraction of Cecropia glaziovii Sneth. Lett Appl Microbiol 51: 143-148.

Sydiskis RJ, Owen DG, Lohr JL, Rosler KH, Blomster RN 1991. Inactivation of enveloped viruses by anthraquinones extracted from plants. Antimicrob Agents Chemother 35: 2463-2466.

Torres R, Modak B, Urzúa A, Monache FD, Damonte E, Pujol CA 2002. Propiedades antivirales de compuestos naturales y semi-sintéticos de la resina de Heliotropium filifolium. Bol Soc Chil Quím 47: 259-263.

Tsuchiya Y, Shimizu M, Hiyama Y, Itoh K, Hashimoto Y, Nakayama M, Horie T, Morita N 1985. Antiviral activity of natural occurring flavonoids in vitro. Chem Pharm Bull 33: 3881-3886.

Yu S, Fang N, Mabry TJ 1987. Flavonoids from Ageratina havanensis. Rev Latinoamericana Quím 18: 20-22.

Zhang X, Hung TM, Phuong PT, Ngoc TM, Min BS, Song KS, Seong YH, Bae K 2006. Anti-inflammatory activity of flavonoids from Populus davidiana. Arch Pharm Res 29: 1102-1108.

\section{*Correspondence}

Gloria del Barrio

Departamento de Microbiología y Virología, Facultad de Biología, Universidad de la Habana

C/ 25, 455 e/ J e I, Vedado, 1040. La Habana, Cuba

gbarrio@infomed.sld.cu

Tel. +5378367941

Fax: +5378321321 